\section{建築生産プロセスを考慮した建 築資材の輸送形態に関する実態 調查・分析}

\author{
名知洋子— * 1 田村雅紀 一 $* 2$ \\ 鈴木道哉 — $* 1$ \\ キーワード : \\ 環境影響，建築資材，輸送形態，システム境界
}

Keywords:

Environmental impact, Building materials, Transportation condition, System boundary

\section{1. 研究の背景と目的}

1997 年に京都で開催された第 3 回気候変動条約締約国会議 (COP3)において京都議定書が採択され，2005 年に発効して以来，温 室効果ガス削減対策の実施が急務となっている。そして，2009 年に 開催された同会議(COP15)での検討により，現在は米国や中国も巻 き込む全世界的な取り組みとして新たな段階を迎えている。

国内では，産業分野別の競争的取り組みが重視され，建築業では 建築物のライフサイクルの各段階を意識した二酸化炭素（以下， $\mathrm{CO} 2$ ）排出量の削減が強く求められている ${ }^{122}$ 。例えば，輸送段階に 限った場合，国内では，建設資材となる原料や製品（部材）は，原 料産地や製造工場などから，小口で多回数の輸送を伴い供給される ことが数多くあり，地理的影響の問題により輸送時環境負荷を増大 させている可能性がある ${ }^{3-5)}$ 。一方で，建築物は，身体材料に加え， 内外装材や建築部品を多種多様に用いるため, 原材料や製品を, 最 終的な消費地に輸送する経路・形態は，建築物の用途・規模・構造 形式をはじめ，原料の加工度ならびに製品（部材）特性に関する依 存性が比較的高くなる可能性がある。さらに昨今は, 地球温暖化対 策に向けた政策的な枠組み ${ }^{6-9)}$ をはじめ, 食料分野での Food Miles ${ }^{10)}$ や，木材分野での Wood Miles ${ }^{11}$ など，製品群の輸送時環境影響を指 標化する動きや，地産地消を重視する自発的取り組みが活発になり つつあり，政策技術の先導性も期待できる状況にあることから，建 築生産全体の輸送時環境負荷の削減に向けて, 時間的・地理的影響 を踏まえた建築資材の環境影響要因に対する出入力情報 (Input/Output)に関する体系的な整理を行い，環境影響を分析する必 要がある。

本研究では, 以上を鑑み，実構造物の生産プロセスを考慮した建 築資材の輸送形態に関する事前調查を行った後に，実施工建築物を 対象に，建築生産プロセスを考慮した建築資材の輸送形態に関わる

\title{
FIELD SURVEY AND ANALYSIS ON TRANSPORTATION CONDITIONS OF BUILDING MATERIALS IN BUILDING CONSTRUCTION PROCESS
}

Yoko NACHI $* 1$

This study intends to analyze techniques and systems to mitigate environmental impacts on transportation load of building materials based on the field survey in building construction process. The procedure of study was as follows, to select the typical steel structure building constructed in Tokyo area, to investigate transportation conditions from raw materials plants to the construction site of building, and finally to analyze the transportation routes/means, loading capacities, and packaging to their transportation conditions. It would be useful to reduce the $\mathrm{CO}_{2}$ emissions due to energy consumption during transportation.
システム境界を設定した上で，資材の輸送経路，輸送手段，荷姿， 積載量に関わる実態調查（調査(1)〜 (3)）を行なう。そして，建築物 の躯体から仕上材を含めた大部分の資材を対象に，材料調達から現 場施工の段階に至るまでの輸送形態が輸送時環境負荷に及ぼす影響 を評価するための基礎資料を得ることを目的とする。

\section{2. 研究概要}

\section{1 調査の流れ}

表 1 に本研究における調查概要を示す。昨今の建築物着工状況を 踏まえるために，総合建設業により所定期間に実施工された建築物 (777 件)の用途, 構造種別等に関する事前調查を行った。その結果, 施工数量の多い資材（躯体工事 5 資材，仕上工事 31 資材）を特定す るとともに，都市圈を中心に着工件数が多い鉄骨造建築物のうち，

\section{表 1 建築資材の輸送形態に関する調査概要}

\begin{tabular}{|c|c|}
\hline 項目 & 内容 \\
\hline 事前調査 & $\begin{array}{l}\text { 平成 } 15 \sim 19 \text { 年に実施工された建築物（全 } 777 \text { 件）の用途, } \\
\text { 構造種別, 建築規模（床面積，階数等)，建設地の分析 }\end{array}$ \\
\hline $\begin{array}{l}\text { 評価対象 } \\
\text { 建築物 }\end{array}$ & $\begin{array}{l}\text { 事前調査を踏まえ, 特定の鉄骨造建築物（東京都江東区内 } \\
\text { 建設地，2009 年建築工事完了）を対象とし，(1)建築資材の } \\
\text { 種類 (躯体工事, 仕上工事), (2)輸送手段・経路, (3)荷姿・ } \\
\text { 積載量 }\left(\mathrm{m}^{2} / \mathrm{m}^{3}\right) \text { をヒアリング・実態調査を実施 }\end{array}$ \\
\hline $\begin{array}{l}\text { 実調査(1) } \\
\text { (資材種類) }\end{array}$ & $\begin{array}{l}\text { 建設資材分類（大分類：構造躯体，仕上材，中分類：適用 } \\
\text { 部位，資材名：建築材料・製品名）をもとに，対象建物に } \\
\text { おける材料・製品の適用実態を調査（躯体工事: } 5 \text { 資材，仕 } \\
\text { 上げ工事 : } 31 \text { 資材より選択） }\end{array}$ \\
\hline $\begin{array}{l}\text { 実調査(2) } \\
\text { (輸送方法) }\end{array}$ & $\begin{array}{l}\text { 実調査(1)を踏まえ, 専門事業者へのヒアリング調査により, } \\
\text { 実際に使用された各建築資材の輸送手段注) (車両種類と積 } \\
\text { 載量) と輸送経路（工場から現場ほか）による輸送方法を } \\
\text { 調査 }\end{array}$ \\
\hline $\begin{array}{l}\text { 実調査(3) } \\
\text { (輸送状態) }\end{array}$ & $\begin{array}{l}\text { 実調査(2)を踏まえ，専門事業者へのヒアリング・現場調査 } \\
\text { により，実に使用された各建築資材の輸送状態（資材の } \\
\text { 原材料・製品状態, 輸送経路, 荷姿の積載状態・量など) }\end{array}$ \\
\hline
\end{tabular}

注）陸上輸送（2，4，10，15，20 tトラック）, 海上輸送（フェリー, コンテナ船）
Institute of Technology, Shimizu Corporation., Dr. Eng.

2 Assoc. Prof., Dept. of Architecture and Urban Design, Fac. of Eng., Kogakuin Univ., Dr. Eng. 
東京都江東区で実施工された鉄骨造建築物（以下，モデル建物）を 評価対象とした（表 2 参照）。

調查(1)では, モデル建物に関する建築資材・製品の種類を, 見積 書と現物確認により特定・整理を行ない, 調査(2)では, 調査(1)の結 果を受け，専門工事業者へのヒアリング調査を通じ，各建築資材の 輸送方法を複数種類に分類し, 最後に調査(3)では, 同様の方法で, 当該資材の輸送状態（資材の原材料・製品状態，輸送経路，荷姿の 積載状態・積載量など）を分析した。

\section{2 モデル建物の資材調達から施エ段階までの環境管理に関わるシ ステム境界の設定}

表 3 に本研究で取り扱った建築資材の環境管理に関わるシステム 境界の枠組みを示す。システム境界(System boundary)は, ISO 14044:2006 Environmental management ${ }^{12)}$ に考え方が示されており, ラ イフサイクルアセスメントの実施に不可欠で, Life cycle stages, Processes, Inputs or outputs の要因分析を重視している。一方, 建設 活動は, ISO14000 seriesにおける組織活動と製品・サービスに関す る環境マネジメントとは相違する特性を踏まえる必要があることか ら, 本研究では, システム境界条件を $\mathrm{A} \sim \mathrm{G}$ の項目に分類し, 整理・ 設定を試みた。その結果, モデル建物に関しては, 技術的境界(A) においては，考慮すべき範囲として製品製造段階(A2)と施工段階 (A3)がある等, 実際の施工業者が, 建築資材の輸送形態の環境影響
を分析する上で必要となるシステム境界条件の範囲を設定すること ができた。その上で, 本研究では, 製品（部材）工場に加工度の低 い「資材の原料( $\left.\mathrm{M}_{1}\right) 」$ と加工度の高い「製品の原料( $\left.\mathrm{M}_{2}\right) 」 を$ 輸送す る原料供給段階（以下，原料サプライ $(\mathrm{S})$ ）と，施工現場に直接製品 （部材）を輸送する場合 $\left(\mathrm{P}_{1}\right)$ と保管倉庫を介して輸送する場合 $\left(\mathrm{P}_{2}\right)$ （以下，製品サプライ）を区分し，建築資材のインプット(In)/アウ トプット(Out)の情報を確認し, 調查(1)〜(3)に基づく各種建築資材の 種類, 輸送方法ならびに輸送形態に関する分析・評価を行った。

\section{表 2 対象建築物の概要}

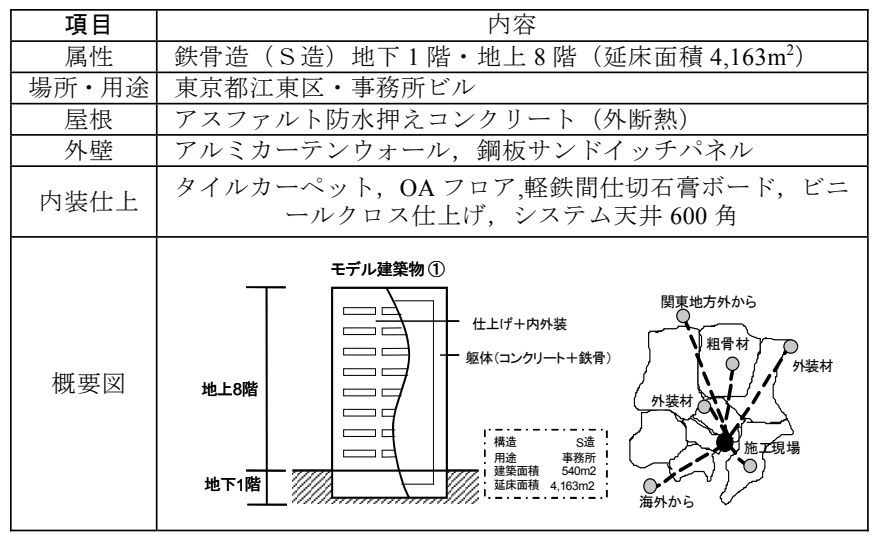

表 3 本研究で取り扱った建築資材の環境管理に関わるシステム境界の枠組み

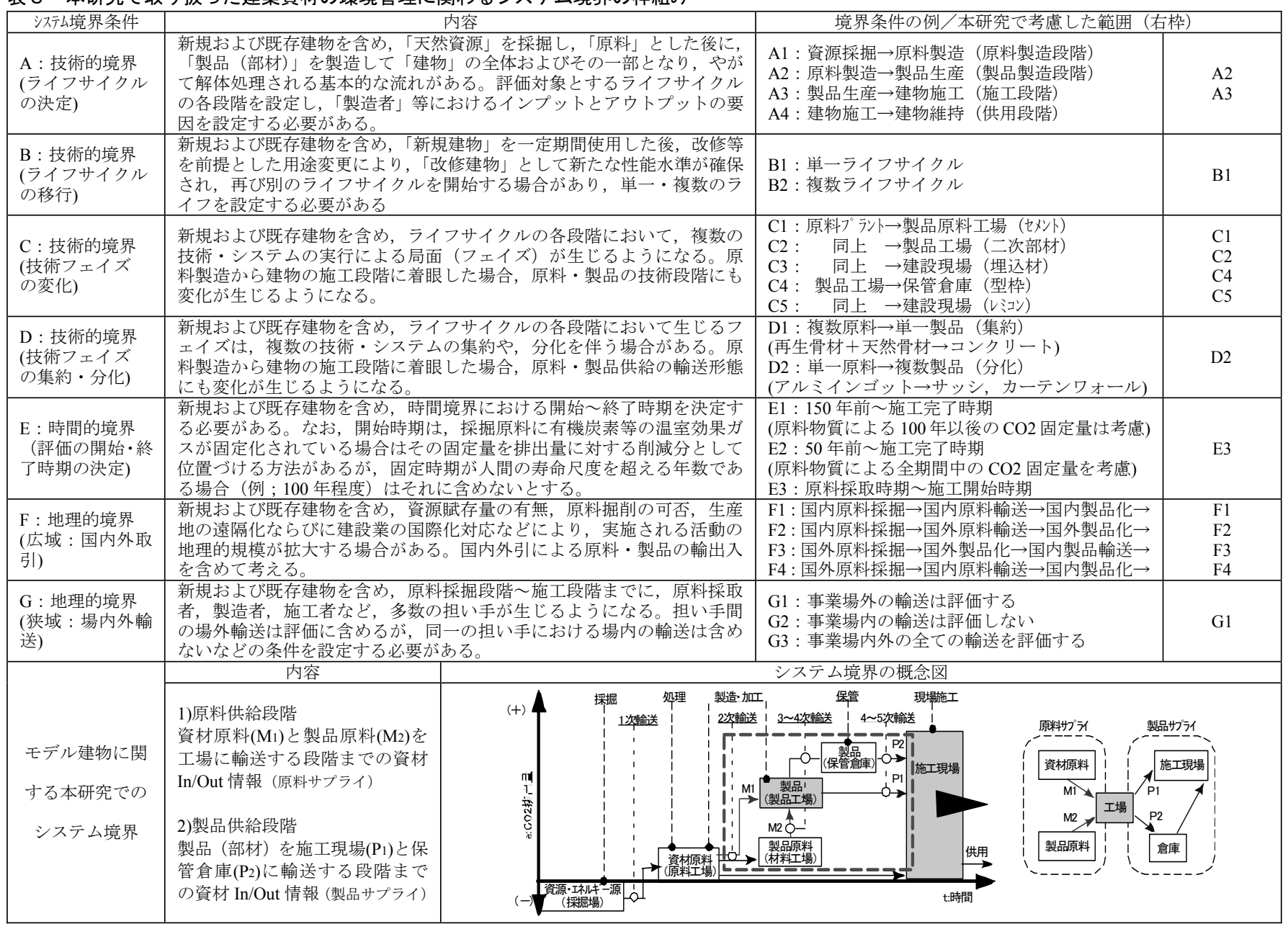




\section{3. 調査結果および考察}

\section{1 調査 $(1)$ 一建築資材の種類}

表 4 にモデル建物に使用された建設資材の一覧を示す。事前調查 において, 設計図書から建築概算コストを算出する見積部へのヒア リングにより比較的部材数量の多いものを抽出している（躯体工事 で 5 資材, 仕上工事で 31 資材)。調査(1)では, この結果を踏まえ, モデル建物の施工現場に実際に輸送された建築資材を躯体工事で 5 資材，仕上工事で 14 資材を分類し，特定した。

\section{2 調査(2)一建築資材の輸送手段と積載重量特性}

表 5 にモデル建物における資材輸送手段と積載重量特性を, 表 6 に資材輸送状態（経路，荷姿，積載量等）の実態調查結果を示す。 調査(1)の結果を踏まえ, 該当する資材について, 専門工事業者へヒ アリング調查を行ったところ, 輸送手段は, 資材の形状・性質・積 載量(重量と容積)により決定し，5種類程度に特定されることがわか った。輸送経路は, 建築資材を工場で製造（加工）して現場へ直送 する資材(原料サプライ)と, 建築資材を工場で製造 (加工)し倉庫 (港) を経由して現場へ輸送する(製品サプライ)の 2 タイプに分けられた。 図 1 に資材輸送手段の特性比率を示す。図 1 a)の車両重量比をみる と, 4ton トラック (平トラック, 幌付トラック, ユニック付トラッ ク）の使用が約 6 割と過半を占め, 仕上工事に関しては 7 割以上が 4ton トラックで輸送されていた。施工現場が都心にあるため，現場 敷地内での資材保管庫が確保されず，工事工程の進渉状況に合わせ て資材が輸送されたためといえる。同様に, 図 1 b)に示すように関東 近県の工場から現場へ直送するケースが過半を占めていた。内装・ 天井材の一部は, 長距離輸送 (愛知県, 石川県, 岡山県) で, 一時 的に倉庫（東京都，神奈川県）に保管し, 現場へは 4ton トラックに 積み替え輸送されていた。石材は, 中国から海外調達されていた。

\section{3 調査(3)-建築資材の輸送形態}

表 7 に資材加工レベル別の荷姿の特性分析結果を, 図 2 にモデル 建物における資材荷姿パターンごとの輸送車数割合を示す。

荷姿パターンは,「密閉」,「平積み」,「ユニット積み」，「平置き」 の 4 つに分類された。また, その荷姿は, 資材の加工レベル（原料, 材料, 製品, 部材) との相関が考えられたため, 荷姿と加工度の関 係も併せて示した。

「密閉」は, 製品形状が定められない「原料レベル」の状態であ り, 液状・粉末状で主に原料・製品工場に輸送され，セメントや混 和材料が該当するが，レディーミクストコンクリートなども例外と して当てはまる。

「平積み」は，断面寸法や厚みが定まった「材料レベル」の状態 であり，原料工場から製品工場にパレットで重㸚積みされて輸送さ れ, 鉄筋, 型枠, 石膏ボード, ALC 板などが該当した。

「ユニット積み」は, 形状寸法が定まった「製品レベル」の状態 であり, 専用架台などで製品工場から施工現場に輸送され, ガラス, 断熱サンドイッチパネル，システム天井などが該当した。

「平置き」は, 製品が組立加工された「部材レベル」の状態であ り, 荷台への平置きや, 梱包養生などで輸送され, 鉄骨本体, アル ミカーテンウォール，スチールドアが該当した。

これらの資材荷姿パターンごとの輸送車数割合のうち,「平積み」, 「ユニット積み」が全体の 8 割を占めており, モデル建物における 資材の加工レベルが輸送形態に影響を及ぼすことが考えられた。
表 4 モデル建物に使用された建築資材の一覧

\begin{tabular}{|c|c|c|c|}
\hline 大分類 & 中分類 & 建築資材名（材料・製品・部材） & モデル建物 \\
\hline \multirow{5}{*}{$\begin{array}{l}\text { 躯体 } \\
\text { 材料 }\end{array}$} & \multirow{3}{*}{$\begin{array}{c}\text { 鉄筋 } \\
\text { コンクリート }\end{array}$} & コンクリート & $\bigcirc$ \\
\hline & & 型枠 & $\bigcirc$ \\
\hline & & 鉄筋 & $\bigcirc$ \\
\hline & \multirow{2}{*}{ 鉄骨 } & 鉄骨本体 & $\bigcirc$ \\
\hline & & 耐火被覆 & $\bigcirc$ \\
\hline \multirow{31}{*}{$\begin{array}{l}\text { 仕上 } \\
\text { 材料 }\end{array}$} & \multirow{3}{*}{ 屋根 } & 金属屋根 & - \\
\hline & & アスファルト防水 & $\bigcirc$ \\
\hline & & 塗膜・塗布防水 & - \\
\hline & \multirow{5}{*}{ 外壁 } & A L C 板 & 0 \\
\hline & & \begin{tabular}{|l|l}
$\mathrm{P}$ C板 \\
\end{tabular} & - \\
\hline & & 断熱サンドイッチパネル & 0 \\
\hline & & タイル & - \\
\hline & & 石 & 0 \\
\hline & \multirow{9}{*}{ 建具 } & アルミカーテンウォール & $\bigcirc$ \\
\hline & & アルミサッシ & - \\
\hline & & ガラスカーテンウォール & - \\
\hline & & \begin{tabular}{|l|l} 
ガラス \\
\end{tabular} & $\bigcirc$ \\
\hline & & スチールドア & $\bigcirc$ \\
\hline & & シャッター & - \\
\hline & & ステンレスドア+ドアエンジン & - \\
\hline & & 木製建具 & - \\
\hline & & 軽量スチールドア & - \\
\hline & \multirow{4}{*}{ 床 } & O A フロア・フリーフロア・二重床 & $\mathrm{O}$ \\
\hline & & 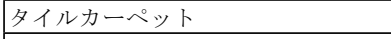 & 0 \\
\hline & & 塩化ビニールシート & 0 \\
\hline & & フローリング & - \\
\hline & \multirow{6}{*}{$\begin{array}{c}\text { 内壁 } \\
\text { · } \\
\text { 天井 }\end{array}$} & 軽鉄下地 & - \\
\hline & & 石膏ボード & 0 \\
\hline & & 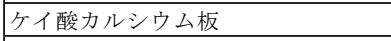 & - \\
\hline & & ビニールクロス & 0 \\
\hline & & 岩綿吸音板 & - \\
\hline & & システム天井 & 0 \\
\hline & \multirow{4}{*}{ 什器 } & トイレブース & 0 \\
\hline & & ユニットバス & - \\
\hline & & 洗面化粧台 & - \\
\hline & & 手摺 & - \\
\hline
\end{tabular}

備考） $\bigcirc$ : 該当 - : 該当せず

表 5 モデル建物における資材輸送手段と車載重量特性

\begin{tabular}{|c|c|c|c|c|c|}
\hline \multirow{2}{*}{ 種類 } & \multirow{2}{*}{ 装備の説明 } & \multicolumn{4}{|c|}{ 車載量 } \\
\hline & & 4 ton & 10ton & 15 ton & 28ton \\
\hline 平トラック & $\begin{array}{l}\text { 荷台に側方のあおりがあるが, 上部 } \\
\text { は無蓋で開放状態にある }\end{array}$ & $\bigcirc$ & $\bigcirc$ & $\bigcirc$ & - \\
\hline 幌付トラック & $\begin{array}{l}\text { 平トラックに, 水濡れや荷痛み防止 } \\
\text { 用の布・鋼製覆い付き荷台を持つ }\end{array}$ & 0 & 0 & - & - \\
\hline \begin{tabular}{|l} 
ユニッック付 \\
トラック \\
\end{tabular} & $\begin{array}{l}\text { 荷扱い用となる小型クレーンが荷 } \\
\text { 台に設置されている }\end{array}$ & $\bigcirc$ & O & - & - \\
\hline トレーラー & $\begin{array}{l}\text { 車両自身に原動機を持たず,専ら牽 } \\
\text { 引されるための車台を有する }\end{array}$ & - & - & - & 0 \\
\hline $\begin{array}{l}\text { トラック } \\
\text { アジテータ }\end{array}$ & $\begin{array}{l}\text { レディーミクストコンクリートを } \\
\text { 擋拌しながら輸送する }\end{array}$ & - & 0 & - & - \\
\hline コンテナ船 & $\begin{array}{l}45 \text { フィート (約 } 13.7 \mathrm{~m}), 40 \text { フィート（約 } \\
12 \mathrm{~m}), 20 \text { フィート (約 } 6 \mathrm{~m}) \text { の標準的 } \\
\text { な鋼製貨物用コンテナを輸送する }\end{array}$ & - & - & - & - \\
\hline
\end{tabular}

備考) $\bigcirc$ : 該当 - : 該当せず

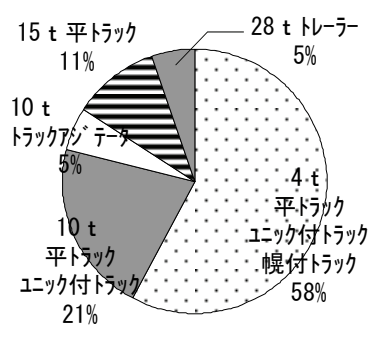

a) 車両重量比

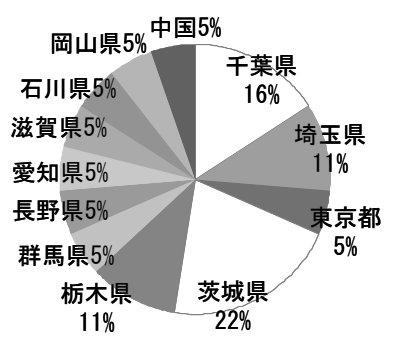

b) 資材輸送先
図 1 モデル建物における資材輸送手段の特性比率 
表 6 モデル建物における資材輸送状態（経路, 荷姿, 積載量等）の実態調査結果

\begin{tabular}{|c|c|c|c|c|c|c|}
\hline 大分類 & 中分類 & 資材名 & 輸送手段 & 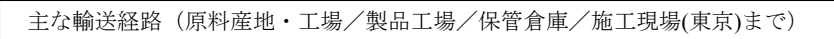 & 荷姿 & 積載量等 \\
\hline \multirow{5}{*}{$\begin{array}{l}\text { 躯体 } \\
\text { 材料 }\end{array}$} & \multirow{3}{*}{$\begin{array}{l}\text { 鉄笳 } \\
\text { コンクリート }\end{array}$} & コンクリート & $\begin{array}{l}\text { トラック } \\
\text { アジテータ }(10 \mathrm{t})\end{array}$ & $\begin{array}{l}\text { 骨材は茨城産・栃木産, セメントは原料工場 (岩手) から搬入し, サービスステ } \\
\text { ーション (東京) を経由してレディーミクストコンクリート場に直送 }\end{array}$ & 密閉 & $4.5 \mathrm{~m}^{3} /$ 台 \\
\hline & & 型枠 & \begin{tabular}{|l|} 
ユニック付 \\
トラック $(4 \mathrm{t})$
\end{tabular} & 原料（木材）を海外より搬入し, 製品工場（千葉）で加工し, 施工現場へ直送 & 平置き & - \\
\hline & & 鉄筋 & トレーラー $(28 \mathrm{t})$ & 製品工場 (栃木県) で製造し, 施工現場へ直送 & 平置き & $25.41 \mathrm{t} /$ 台 \\
\hline & \multirow{2}{*}{ 鉄骨 } & 鉄骨本体 & 平トラック $(10 \mathrm{t})$ & 原料（製鉄）を原料工場より搬入，製品工場（茨城）で加工し，施工現場へ直送 & 平置き & $7 \mathrm{t} /$ 台 \\
\hline & & 耐火被覆 & 平トラック $(10 \mathrm{t})$ & 原料（岩石）を原料工場より搬入, 製品工場（長野）で加工し, 施工現場へ直送 & 平積み & $10,920 \mathrm{~m}^{2} /$ 台 \\
\hline \multirow{13}{*}{$\begin{array}{l}\text { 仕上 } \\
\text { 材料 }\end{array}$} & \multirow{4}{*}{ 外壁 } & A L C 板 & 平トラック $(15 \mathrm{t})$ & 原料（セメント, 骨材など）を原料工場より搬入, 製品工場（茨城県）から直送 & 平積み & $200 \mathrm{~m}^{2} /$ 台 \\
\hline & & 断熱形ドイ伊パ礼 & 平トラック $(15 \mathrm{t})$ & 製品工場（滋賀）から, 施工現場一直送 & ユニット積み & $260 \mathrm{~m}^{2} /$ 台 \\
\hline & & \multirow{2}{*}{ 石材 } & $\begin{array}{l}\text { コンテナ船 } \\
(20 \text { フィート) }\end{array}$ & \multirow{2}{*}{$\begin{array}{l}\text { 原料（岩石）を原料工場で採取および加工を施し, 港（神奈川）まで航路輸送し, } \\
10 \mathrm{t} ト ラ ッ ク ゙ \text { 現場へ直送 }\end{array}$} & 平積み & $\begin{array}{l}18 \text { パレット } \\
\text { ルンテナ }\end{array}$ \\
\hline & & & \begin{tabular}{|l|} 
ユニック付 \\
トラック (10t) \\
\end{tabular} & & 平積み & $110 \mathrm{~m}^{2} /$ 台 \\
\hline & \multirow{2}{*}{ 建具 } & アル氻ーデンウール & 平トラック $(4 \mathrm{t})$ & 原料（押出成形品）を原料工場より搬入，製品工場（茨城）から施工現場へ直送 & 平置き & - \\
\hline & & スチールドア & 平トラック $(4 \mathrm{t})$ & 原料（鋼板）を原料工場より搬入, 製品工場（群馬）から施工現場へ直送 & 平置き & $57.6 \mathrm{~m}^{2} /$ 台 \\
\hline & \multirow{3}{*}{ 床 } & OAフロア & 平トラック $(10 \mathrm{t})$ & 原料（セメント等）を原料工場より搬入，製品工場（茨城）から施工現場へ直送 & ユニット積み & $200 \mathrm{~m}^{2} /$ 台 \\
\hline & & 多仍一ペット & 平トラック $(4 \mathrm{t})$ & 原料（ナフサ類）を原料工場より搬入，製品工場（埼玉県）から施工現場へ直送 & ユニット積み & $760 \mathrm{~m}^{2} /$ 台 \\
\hline & & 塩化ビニールシート & 平トラック $(4 \mathrm{t})$ & 原料（ナフサ類）を原料工場より搬入，製品工場（埼玉県）から施工現場へ直送 & 平積み & $1,300 \mathrm{~m}^{2} /$ 台 \\
\hline & \multirow{3}{*}{$\begin{array}{c}\text { 内壁 } \\
\text { 天井 }\end{array}$} & 石膏ボード & 平トラック $(4 \mathrm{t})$ & 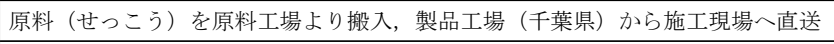 & 平積み & $500 \mathrm{~m}^{2} /$ 台 \\
\hline & & ビニールクロス & 平トラック $(4 \mathrm{t})$ & 製品工場（愛知）から倉庫（東京）へ輸送, $4 \mathrm{t}$ トラックで施工現場へ直送 & 平積み & $1,800 \mathrm{~m}^{2} /$ 台 \\
\hline & & システム天井 & 平トラック $(4 \mathrm{t})$ & 製品工場（岡山）から倉庫（神奈川）へ輸送, $4 \mathrm{t}$ トラックで施工現場へ直送 & ユニット積み & $69.12 \mathrm{~m}^{2} /$ 台 \\
\hline & 什器 & トイレブース & 幌付トラック (4t) & 製品工場（石川）から倉庫（東京）へ輸送, $4 \mathrm{t}$ トラックで施工現場へ直送 & ユニット積み & 40 ブース/台 \\
\hline
\end{tabular}

表 7 モデル建物における資材加エレベル別の荷姿の特性分析

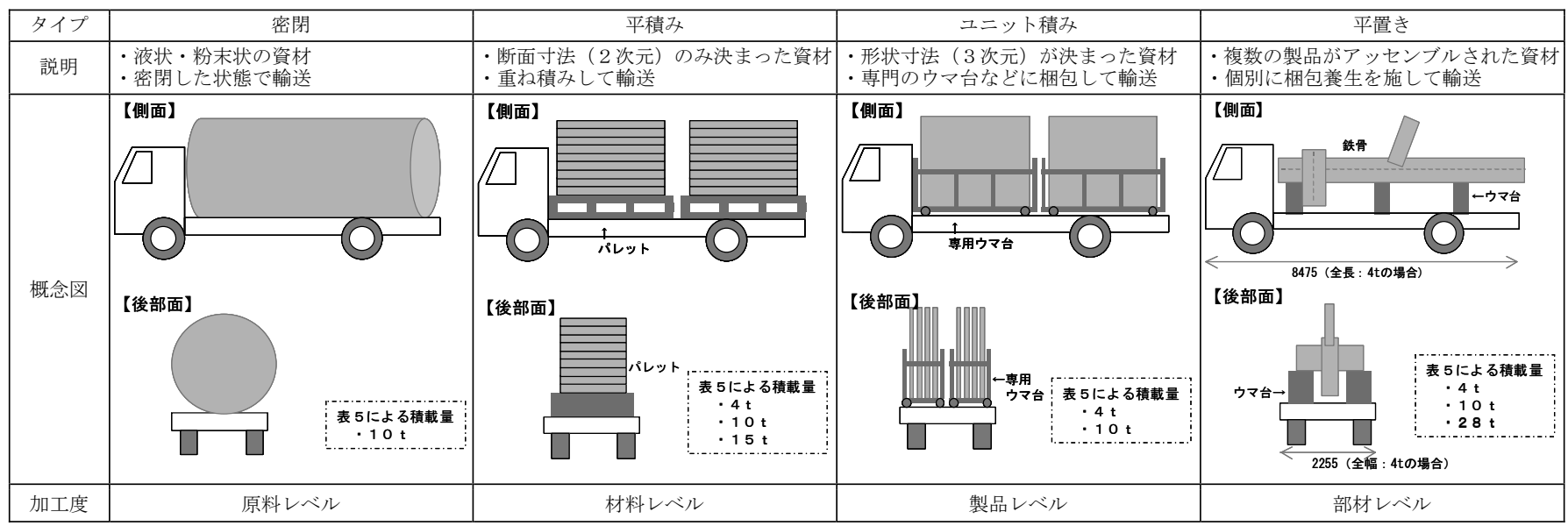

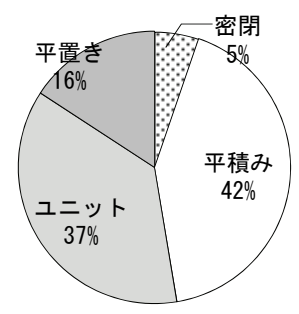

図 2 モデル建物における資材荷姿パターンごとの輸送車数割合

以上の検討により，資材の加工レベルと輸送手段には相関がある ことが考えられた。表 8 に資材荷姿パターンの立則条件を示す。荷 姿は, 積み荷の嵪密度と車両積載量との関係より, 資材重量で積載 限度が決まる「 $\mathrm{A}($ 重量型 $) 」 と$, 資材容積で積載限度が決まる「B(容 積型)」に分類される。資材の見かけの嵩密度 $\alpha$ は積み荷固有の特性
表 8 資材の荷姿パターンの立則条件

$\mathrm{A}($ 重量型)：資材重量で積載限度決定 $\mathrm{B}$ (容積型)：資材容積で積載限度決定

\begin{tabular}{c|c}
$\alpha \geqq \beta$ & $\alpha<\beta$
\end{tabular}

$\alpha:$ 棝包込み資材の見かけの嵩密度 $\left(\mathrm{t} / \mathrm{m}^{3}\right)$

$\beta$ : 車両ごとに決まる積み荷 (空間込み) の見かけの嵩密度 $\left(\mathrm{t} / \mathrm{m}^{3}\right)$

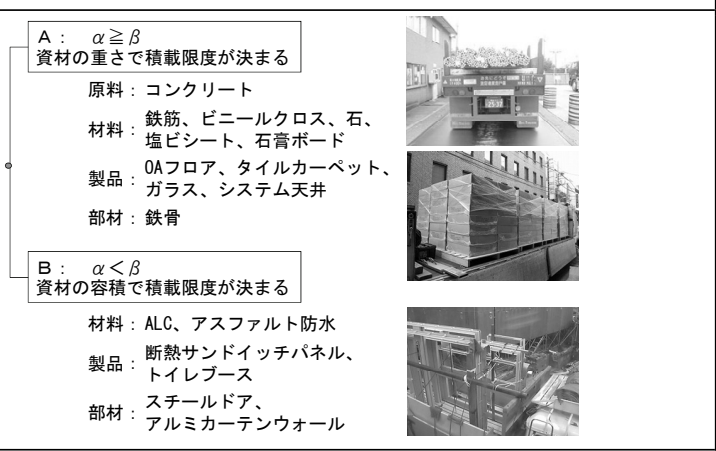


值であり, 車両の最大積載限度 $\beta$ は車両固有の特性值とし, $\alpha \geqq \beta$ の関係が成立した場合，輸送形態は資材重量で決定され， $\alpha<\beta$ の 関係が成立した場合，資材の嵩密度で積載限度が決定される。

表 9 にモデル建築の各資材の嵩密度と荷姿パターンの推定值を示 す。各資材ごとに輸送車両の寸法值と, 実資料の寸法と重量值を用 いて (図面および写真判定による概算值を含む), 見かけの嵩密度 $\alpha$, $\beta$ を計算で求めた。 $\alpha$ が 1 を上回るような見かけの嵩密度が大きい 資材は「 $\mathrm{A}$ (重量型)」となり， $\alpha$ が 0.5 を下回るような資材は「B(容 積型 $) 」$ となるまた実態調査により,「 $\mathrm{A}($ 重量型 $) 」 と 「 \mathrm{~B}($ 容積型 $) 」$ の分布は, 資材の加工度により一定の傾向があることが考えられた。

図 3 にモデル建物の各資材の嵩密度と加工度との関係を車載量 (28ton, 15ton,10ton,4ton)ごとに示す。各車両に固有の積載方法の A 值, $\mathrm{B}$ 值による荷姿パターンの閾值を求め, 実際に輸送された各資材の 嵩密度を示すと, 多くの材料が資材重量で輸送形態が決まっており, 推定值で示寸傾向之同様になっている。なお，加工度が高い仕上材 や，製品工場での組立・加工を行った部品・製品は，嵩密度の低い ものが多く，B值の領域に含まれる傾向にある。

\section{4 建築資材の輸送形態のモデル化}

表 10 に建築資材の輸送形態モデルの事例を示す。調查(1)〜 (3)によ るアンケート・実態調査・分析に基づき，モデル建物に関するシス テム境界の設定条件を踏まえ，建築資材の種類，輸送方法ならびに 輸送形態（荷姿）から導かれる原料・製品工場から施工現場までの 輸送解体を資材ことにパターン化した。また, 輸送経路に関しては, 表 3 におけるシステム境界の設定条件に従い，原料サプライと製品 サプライに分類した。原料サプライは, 資材原料を現地から調達し, 工場へ輸送する経路（M1），資材原料を工場で製品化し製品原料とし て調達し，工場へ輸送する経路（M2）となる。製品サプライは，建 築資材を工場から直接現場へ輸送する経路（P1）, 工場から途中倉庫 一仮置きしてから現場へ輸送する経路（P2）となる。

例えば，鉄骨は，「原料（製鉄）を原料工場より搬入，製品工場（茨 城）で加工し，施工現場へ直送」する経路をとるため，原料サプラ イ(M2)と製品サプライ $(\mathrm{P} 1)$ の組み合わせとして設定でき, 輸送経路パ

表 9 モデル建物の各資材の嵩密度と荷姿パターンの推定値

\begin{tabular}{|c|c|c|c|c|c|}
\hline 加工度 & $\begin{array}{c}\text { 車載量 } \\
\text { (ton) }\end{array}$ & 資材名 & $\begin{array}{c}\alpha^{* 1} \\
\left(\mathrm{t} / \mathrm{m}^{3}\right)\end{array}$ & $\begin{array}{c}\beta^{* 2} \\
\left(\mathrm{t} / \mathrm{m}^{3}\right)\end{array}$ & $\begin{array}{l}\text { 荷姿 } \\
\text { パタ-y }\end{array}$ \\
\hline 原料 & 10 & コンクリート & 2.3 & 2.2 & A \\
\hline \multirow{8}{*}{ 材料 } & 28 & 鉄筋 & 0.5 & 0.3 & $\mathrm{~A}$ \\
\hline & \multirow{2}{*}{15} & ビニルクロス & 7.8 & 0.4 & A \\
\hline & & ALC & 0.6 & 0.7 & $\mathrm{~B}$ \\
\hline & 10 & 石 & 1.6 & 0.7 & $\mathrm{~A}$ \\
\hline & \multirow{4}{*}{4} & 塩ビシート & 1.6 & 0.5 & $\mathrm{~A}$ \\
\hline & & 石膏ボード & 0.8 & 0.3 & $\mathrm{~A}$ \\
\hline & & 型枠 & 0.7 & 0.3 & A \\
\hline & & アスファルト防水 ${ }^{* 3}$ & 0.1 & 0.3 & $\mathrm{~B}$ \\
\hline \multirow{6}{*}{ 製品 } & 15 & 断熱サンドイッチパネル & 0.4 & 0.7 & $\mathrm{~B}$ \\
\hline & 10 & $\mathrm{OA}$ フロア & 0.5 & 0.3 & $\mathrm{~A}$ \\
\hline & \multirow{4}{*}{4} & タイルカーペット & 1.0 & 0.5 & $\mathrm{~A}$ \\
\hline & & ガラス & 0.7 & 0.3 & $\mathrm{~A}$ \\
\hline & & システム天井 & 0.3 & 0.3 & $\mathrm{~A}$ \\
\hline & & トイレブース & - & 0.3 & $\mathrm{~B}$ \\
\hline \multirow{3}{*}{ 部材 } & 10 & 鉄骨 & 1.1 & 0.5 & $\mathrm{~A}$ \\
\hline & \multirow{2}{*}{4} & スチールドア (枠) & 0.2 & 0.3 & $\mathrm{~B}$ \\
\hline & & アルミ CW & 0.2 & 0.3 & B \\
\hline
\end{tabular}

ターンについては $\mathrm{M} 2 \rightarrow \mathrm{P} 1$ と表現することができる。また同時に, おおよその輸送距離についても特定することができた。そして，荷

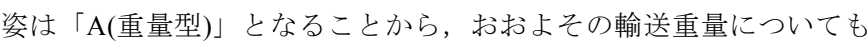
仮定することができる。これらの情報は，最終的にトンキロ法に基 づく各建設資材の輸送時の環境負荷量を算出寸るための基礎的情報 として位置づけることができる。

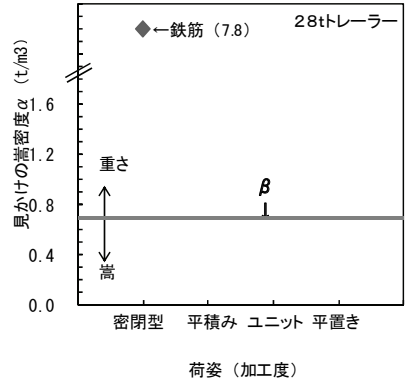

a) 車載量 (28ton)

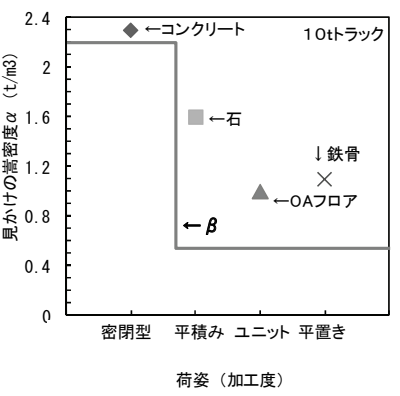

c) 車載量 (10ton)

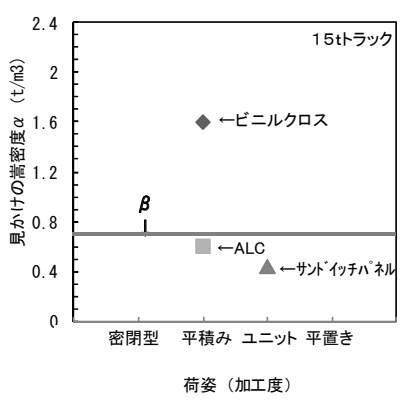

b) 車載量 (15ton)

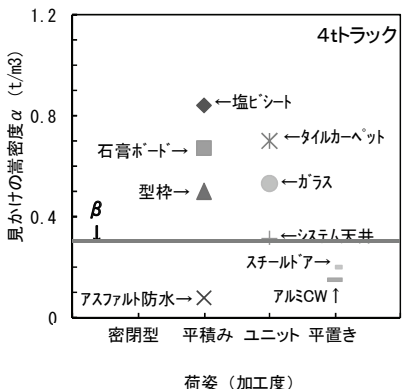

d) 車載量 (4ton)
図 3 モデル建物の各資材の嵩密度と加工度との関係

表 10 建築資材の輸送形態モデルの事例

\begin{tabular}{|c|c|c|c|c|c|c|}
\hline 大分類 & $\begin{array}{l}\text { 中分 } \\
\text { 類 }\end{array}$ & 資材名 & 原料 S & 製品 S & 輸送パターン & 荷姿 \\
\hline \multirow{5}{*}{ 躯体 } & \multirow{3}{*}{$\begin{array}{c}\text { 鉄筋 } \\
\text { コンクリ- } \\
\text { 卜 }\end{array}$} & コンクリート & M2 & P1 & $\mathrm{M} 2 \rightarrow \mathrm{P} 1$ & $\mathrm{~A}$ \\
\hline & & 型枠 & M2 & $\mathrm{P} 1 \cdot \mathrm{P} 2$ & $\mathrm{M} 2 \rightarrow \mathrm{P} 1 \cdot \mathrm{M} 2 \rightarrow \mathrm{P} 2$ & A \\
\hline & & 鉄筋 & M2 & P1 & $\mathrm{M} 2 \rightarrow \mathrm{P} 1$ & A \\
\hline & \multirow{2}{*}{ 鉄骨 } & 鉄骨本体 & M2 & P1 & $\mathrm{M} 2 \rightarrow \mathrm{P} 1$ & A \\
\hline & & 耐火被覆 & M2 & P1 & $\mathrm{M} 2 \rightarrow \mathrm{P} 1$ & B \\
\hline \multirow{14}{*}{ 仕上 } & 屋根 & アスファルト防水 & M2 & P1 & $\mathrm{M} 2 \rightarrow \mathrm{P} 1$ & B \\
\hline & \multirow{3}{*}{ 外壁 } & A L C 板 & M1 & P1 & $\mathrm{M} 1 \rightarrow \mathrm{P} 1$ & B \\
\hline & & $\begin{array}{l}\text { 断熱サンドイッチ } \\
\text { パネル }\end{array}$ & M2 & P1 & $\mathrm{M} 2 \rightarrow \mathrm{P} 1$ & B \\
\hline & & 石 & $\mathrm{M} 1 \cdot \mathrm{M} 2$ & P1 & $\mathrm{M} 1 \rightarrow \mathrm{P} 1 \cdot \mathrm{M} 2 \rightarrow \mathrm{P} 1$ & B \\
\hline & \multirow{3}{*}{ 建具 } & $\begin{array}{l}\text { アルミカーテンウ } \\
\text { オール }\end{array}$ & M2 & P1 & $\mathrm{M} 2 \rightarrow \mathrm{P} 1$ & B \\
\hline & & ガラス & M1 & P1 & $\mathrm{M} 1 \rightarrow \mathrm{P} 1$ & A \\
\hline & & スチールドア & M2 & P1 & $\mathrm{M} 2 \rightarrow \mathrm{P} 1$ & B \\
\hline & \multirow{3}{*}{ 床 } & O Aフロア & $\mathrm{M} 1 \cdot \mathrm{M} 2$ & $\mathrm{P} 1 \cdot \mathrm{P} 2$ & $\begin{array}{c}\mathrm{M} 1 \rightarrow \mathrm{P} 1 \cdot \mathrm{M} 1 \rightarrow \mathrm{P} 2 \\
\mathrm{M} 2 \rightarrow \mathrm{P} 1 \cdot \mathrm{M} 2 \rightarrow \mathrm{P} 2 \\
(\mathrm{ALL})\end{array}$ & A \\
\hline & & カーペットタイル & M2 & $\mathrm{P} 1 \cdot \mathrm{P} 2$ & $\mathrm{M} 2 \rightarrow \mathrm{P} 1 \cdot \mathrm{M} 2 \rightarrow \mathrm{P} 2$ & A \\
\hline & & $\begin{array}{l}\text { 塩化ビニールシー } \\
\text { ト }\end{array}$ & M2 & $\mathrm{P} 1 \cdot \mathrm{P} 2$ & $\mathrm{M} 2 \rightarrow \mathrm{P} 1 \cdot \mathrm{M} 2 \rightarrow \mathrm{P} 2$ & A \\
\hline & \multirow{3}{*}{$\begin{array}{l}\text { 内壁 } \\
\cdot \\
\text { 天井 }\end{array}$} & 石膏ボード & $\mathrm{M} 1 \cdot \mathrm{M} 2$ & P1 & $\mathrm{M} 1 \rightarrow \mathrm{P} 1 \cdot \mathrm{M} 2 \rightarrow \mathrm{P} 1$ & $\mathrm{~A}$ \\
\hline & & ビニールクロス & $\mathrm{M} 1 \cdot \mathrm{M} 2$ & P1 & $\mathrm{M} 1 \rightarrow \mathrm{P} 1 \cdot \mathrm{M} 2 \rightarrow \mathrm{P} 1$ & $\mathrm{~A}$ \\
\hline & & システム天井 & M1 & P2 & $\mathrm{M} 1 \rightarrow \mathrm{P} 2$ & A \\
\hline & 什器 & トイレブース & M2 & $\mathrm{P} 1 \cdot \mathrm{P} 2$ & $\mathrm{M} 2 \rightarrow \mathrm{P} 1 \cdot \mathrm{M} 2 \rightarrow \mathrm{P} 2$ & B \\
\hline
\end{tabular}


以上の流れにより, 具体的な建築物に関する建築生産プロセスを 考慮した建築資材全体の輸送時環境負荷量の評価を行うことが可能 と考えられる。また, 今後は, 建築資材全体の輸送の効率化や共同 配送などを含めたモーダルシフト対策を具体的に提示し，国内全体 の建築資材に関わる輸送時環境負荷量を削減するために, 鉄骨造建 築物に限らず，鉄筋コンクリート造建築物や木造建築物などの構造 種別を含めた輸送形態モデルについても評価する必要がある。

\section{4. まとめ}

本研究により, 以下の知見が得られた。

1) 東京都に建設された一般的な鉄骨造建築物を対象に, 建築生産プ ロセスにおけるシステム境界を設定した上で, 現場に輸送された 構造躯体・仕上材別の建築資材の種類を具体的に特定した。

2) モデル建物における各種建築資材について, ヒアリングと実態調 查により, 施工現場への輸送手段を明らかにするとともに, 輸送 経路，資材荷姿などによる輸送形態を具体的に示した。

3) モデル建物における各種建築資材の積み荷の属性を, 資材荷姿の 分析結果より, 原料・材料・製品・部材の 4 レベルに区分し, そ れぞれの嵩密度の算定值と, 車両積載限度との関係より, 資材重 量で積載限度が決まる「 $\mathrm{A}($ 重量型 $) 」 と$ 資材容積で積載限度が決ま る「B(容積型 $) 」 に$ 特定した。

4) モデル建物における各種建築資材の輸送形態について, 原料が工 場に輸送される経路（原料サプライ）と製品が現場に輸送される 経路（製品サプライ）に区分した上で, 各種建築資材における施 工現場に到着するまでの輸送形態を, 両者の組み合わせよりモデ ル化した。

5) 鉄骨造の建築物を対象に，各種建築資材の輸送手段を特定したう えでの輸送重量と輸送距離の概算值が整理され, 最終的にトンキ 口法に基づく輸送時の環境負荷量を算出するうえで必要となる基 礎的情報が整理された。

\section{謝辞}

本研究の実施にあたり，清水建設㑣建築事業本部調達総合センタ 一 高橋昭氏, 関東支店見積部 新井弘美氏, 各専門工事業者の方々 にヒアリング等実施調查で助力を得た。また, 平成 21 年度工学院大 学, 都市減災センタープロジェクト (中課題 3) の研究補助を受けた。 ここに記して感謝の意を表する。

\section{参考文献}

1) 日本建築学会, 地球環境委員会, サステナブルビルディング普及のための提 言(改訂版), 2007

2) コンクリート工学協会, 環境時代におけるコンクリートイノベーション, コンクリート構造物の環境性能に関寸る研究委員会, 2008.8

3) 田村雅紀, 阿部道彦, 首都圏に流入するコンクリート用骨材の需要動向調 査と輸送時環境負荷評価, 日本建築学会技術報告集, 第 31 号, pp.631-636, 2009.10

4) 岩田彩子, 兼松学, 野口貴文, 長井宏憲, 北垣亮馬, 藤本郷史, 実態調査に 基づくコンクリート関連産業の CO2 排出原単位に及ぼす地域特性・工場規 模の影響, 日本建築学会技術報告集, 第 32 号, pp.43-48, 2009.2

5) 川鍋亜衣子, 飯島泰男, 秋田典子, 清家清, 板垣直行, 木造住宅の国産・輸入 製材の生産から施工地輸送までの二酸化炭素排出量と算定上の問題整理, 日本建築学会技術報告集, 第 32 号, pp.37-42, 2009.2

6) 経済産業省, “カーボンフットプリント制度の実用化・普及推進研究会”, http://www.meti.go.jp (参照 2010-2)

7) 環境省, “温室効果ガス「見える化」推進戦略会議”, http://www.env.go.jp (参 照 2010-2)

8) 経済産業省資源エネルギー庁：ロジスティックス分野における $\mathrm{CO} 2$ 排出量 共同ガイドライン, 2006

9) 国土交通省，モーダルシフト促進アクションプログラム,2004

10) 中田哲也, フードマイレージとその環境に及ぼす負荷に関する考察, 農林 水産政策研究, 第 5 号, 2003

11) ウッドマイルズ研究会, ウッドマイルズ 地元の木を使うこれだけの理由, 農山漁村文化教会, 2007

12) ISO 14044:2006 Environmental management - Life cycle assessment Requirements and guidelines, 2006

13）国土交通省，自動車交通局，道路運送車両法, 2008

[2010 年 2 月 19 日原稿受理 2010 年 4 月 5 日採用決定］ 